\title{
A Magyar Királyi Honvédség nehéz géppuska fejlesztése \\ III. rész
}

\section{A 20 MILLIMÉTERES ÜRMÉRET}

1941. január 25-én, a Katonai Főcsoport főnökének vezetésével tartott értekezleten, a Danuvia Fegyver- és Lőszergyár Részvénytársaság foglalkoztatása mellett, felvetődött a harcjármúvek fegyverzetének végleges megállapításának kérdése is. Az egyes harcjárművek fedélzeti fegyvereinek értékelésén túl megállapították, hogy a részvénytársaság gyártmányai a Gebauer- és Király-féle 20 milliméteres nehéz géppuskák a hasonló, külföldi gyártmányoknál nagyobb teljesítményűek voltak és rendszeresített tölténnyel üzemeltek (pl.: a dán Madsen nehéz géppuska tölténye nem volt rendszeresítve), tömeggyártásuk megindulását követően véglegesen felválthatták volna az ideiglenesen beépített fedélzeti fegyvereket (pl.: 1936M 20 milliméteres nehézpuska). ${ }^{39}$

1931-ben a Danuvia Ipari és Kereskedelmi Részvénytársaságot a Légügyi Hivatal felkérte, hogy egy 20 milliméteres ürméretű Gebauer rendszerű forgógyűrűs (megfigyelő) nehéz géppuskát szerkesszen. Ezt követően a szerkesztő és egyben a cég műszaki igazgatója, Gebauer Ferenc sikertelenül próbálkozott (úgy a megbízónál, mint a Haditechnikai Intézetnél) hozzájutni a kiinduló adatokhoz. A részvénytársasság 1931. szeptember 10-i levelében készségesen vállalta a megbízást, mivel, megítélésük szerint felkészültségük és a Gebauer gázdugattyús rendszer garantálta az új konstrukció hadihasználhatóságát. Azonban a gazdasági helyzetben a kísérleti példány elkészítésének költségeit a cég nem tudja kigazdálkodni, így szükségesnek látszott a forgógyűrű nélküli prototípus elkészítésére egy (a külföldi áraknál szolidabb) ${ }^{40} 30000$ pengős megrendelés. A mintapéldány elkészítések többletköltségeit - a jövőbeni megrendelés reményében - a vállalat magára vállalta, és a nehéz géppuska első változatának elkészítését körülbelül hat hónapra becsülte. A Haditechnikai Intézet 1931. október 9-én az ajánlatot/bejelentést köszönettel tudomásul vette, azonban a megrendeléstől költségvetési korlát miatt belátható időre el kellett tekinteni, annál is inkább mivel a légvédelmi nehéz géppuska követelményeit még nem tisztázták teljesen. ${ }^{41}$

Ennek ellenére a légierő és a páncélos csapatok mellett a folyamerő is benyújtotta az igényét nehéz géppuskára. Például: 1933-ban a vértezett motoros tervezésekor a 2 darab 8 milliméteres szabvány (1907/31 M Schwarzlose) géppuska mellett 2 darab 20 milliméteres nehézgéppuskával is számoltak. ${ }^{42}$

16. ábra. A vértezett motoros hajó terve 2 darab 20 milliméteres nehéz géppuskával

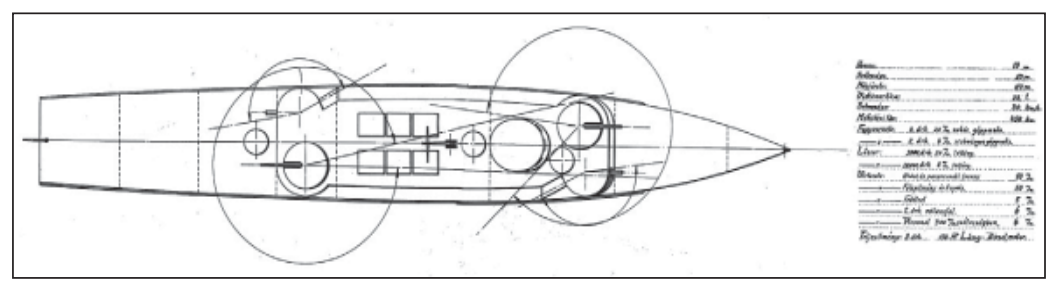

Hosszú évekig a nehéz géppuska frontján látszólag nem történt semmi, azonban a háttérben a Danuvia Ipari és Kereskedelmi Részvénytársaság kísérleti műhelyében lázas tevékenység folyt. Ennek eredményéről a Légügyi Hivatal 1937. október 13-án számolt be. Jelentette, hogy a részvénytársaságnál befejezés előtt állt egy Gebauer rendszerű, 1936M 20 milliméteres nehézpuska töltényét felhasználó repülőgép nehéz géppuska mintapéldánya. Mivel a Ju 86-os repülőgépnél feltétlenül szükség volt egy hasonló űrméretú nehéz géppuskára, kérte a 3a osztály intézkedését a gyors befejezéshez és az előírt próbák végrehajtásához. Valamint tájékoztatást kértek a lőfegyver elkészülésének idejéről. A Honvédelmi Minisztérium kiadvány-tervezetéből kitűnt, hogy a nehéz géppuska november közepére készült el, kipróbálását is akkorra tervezték. Elsődleges információ szerint súlya $25 \mathrm{~kg}$ és tűzgyorsasága percenként 800 lövés volt, részletes tájékoztatással a bemutatón a konstruktőr Gebauer Ferenc, a részvénytársaság műszaki igazgatója szolgált. ${ }^{43}$

1938. november 4-én a Haditechnikai Intézet jelentette, hogy a (1939M felderítő) páncélgépkocsiba és az 1938M Toldi könnyű harckocsiba a 1936M nehézpuska beépítési kísérlet csak szükségmegoldást eredményez. $\mathrm{E}$ helyett a Gebauer rendszerű 20 milliméteres nehéz géppuska befejezéséhez 40000 pengőt és 5000 pót- és 2000 repesz-, valamint 1000 darab páncélgránátot kért. A III. csoportfönökség a 2 centiméteres nehéz géppuska beépítésének elrendelését és az átépítési munkákhoz kért összeg, valamint a lőpróbák lőszerszükségletét ( 82000 pengő), öszszegségében 122000 pengő kiutalását csak abban az esetben javasolta, ha a Danuvia kérdéses gyártmánya a lőfegyverprobléma végleges megoldását jelentette volna. Az 1. vkf. osztály az előterjesztést támogatta, megítélésük szerint a Gebauer-féle nehéz géppuska nemcsak a páncélés harckocsi toronyfegyverének, de repülőgép szárnygéppuskának, sőt légvédelmi nehéz géppuskának is megfelelő. A nehéz géppuska végleges kivizsgálását csak akkor javasolták végrehajtani, ha a rendszeresítésre (az előzetes eredmények, adatok és a vezetőségi bemutató alapján) meglapozott a remény. A honvédelmi vezetés kiadványban szólította fel a Danuvia Ipari és Kereskedelmi Részvénytársaságot, hogy a 2 centiméteres nehéz géppuskát a legrövidebb időn belül egy lőpróba keretében mutassa be. ${ }^{44}$

1939. február 10-én a Haditechnikai Intézet parancsnoka jelentette, hogy a Gebauer rendszerű 20 milliméteres nehéz géppuska elkészült. A mintapéldány teljes körű kivizsgálása még nem fejeződött be, azonban a kipróbálás alapján megállapítható, hogy eltérő tűzgyorsasággal, különböző feladatra lesz alkalmas. Percenként 400 lövésszámnál a Toldi könnyű harckocsi nehéz géppuskájaként, növelt tűzgyorsasággal ( 8000 lövés/perc) repülőgép szárnygéppuskaként is felhasználható. Az új automata lőfegyver bemutatóját 1939. február 28án, 10.00 órakor javasolta megtartani. A III. csoportfőnökség vezetőjének döntése 
alapján a nehéz géppuska kipróbálásán csak a Haditechnikai Intézet vett részt és a tapasztalatok értékelését követően tekintette meg azt a vezetőség. ${ }^{45}$

1939. március 2-án a Haditechnikai Intézet parancsnoka jelentésben számolt be a Gebauer-féle 20 milliméteres nehéz géppuska prototípusának február 28-i bemutatásáról. Gebauer Ferenc bemutatta közel kétéves szerkesztői munkával előállított automatáját, amelyet a Honvédelmi Minisztérium megbízásából (?) repülőgépbe történő beépítésre szerkesztett. A követelmény egyik sarkalatos pontja volt, hogy a tüzgyorsasága legalább $50 \%$-kal múlja felül a külföldi vetélytársait. Az új gázdugattyús automata a konstruktőr lőfegyvereinek elvén építkezett és az 1936M nehézpuska töltényét tüzelte. $A$ bemutatott minta néhány kisebb hiányossággal rendelkezett, ezek korrekciójára a megoldások (vagy tervezőasztalon, vagy a kísérleti műhelyben) rendelkezésre álltak. A jobbítással párhuzamosan egyszerüsítésre és tetemes súlycsökkentésre is sor került, és a további próbákat a május végére elkészült módosított mintával végezték. Mindennek ellenére a parancsnok javasolta az eredeti kísérleti minta bemutatását, amely meggyőzheti a résztvevőket, hogy az ígéret valósággá vált, amellyel ezután már számolni is lehetett. ${ }^{46}$

1940. április 12-én a Haditechnikai Intézet parancsnoka a páncélos járművekbe beépítésre kerülő 20 mm-es nehéz géppuskák első mechanikai és működési próbáihoz az 1936M 20 milliméteres nehéz puska lőszerből 2000 darab pót-páncélgránát fényjelzővel, 2000 darab pót-repeszgránát, 500 darab páncélgránát fényjelzővel és 500 darab repeszgránát kiutalását kérte. Az igényelt lőszer a Haditechnikai Intézet örkénytábori kísérleti állomásán került felhasználásra. ${ }^{47}$

Majd 1941. február 19-én a Haditechnikai Intézet a Király-féle 20 milliméteres nehéz géppuskák üzemi kísérleteihez 1000 darab 1936M 20 milliméteres pót-páncélgránát kiutalását kérte. Az igényelt lőszer költsége (egyenlő megosztásban) a Danuvia Fegyver- és Lőszergyár Részvénytársaságot, illetve az igénylőt terhelte. Majd 1941. október 23-án a Danuvia Fegyver- és Lőszergyár Részvénytársaság, a Haditechnikai Intézet megrendelésére szerkesztett 20 milliméteres kísérleti nehéz géppuskával elkészült, sőt azzal párhuzamosan egy hasonló ürméretű, de más rendszerű lőfegyverrel is kísérleteztek. Ezek működési próbái sok lőszert igényeltek, amelyeket a veszprémi lőszergyár selejtnek minősített lőszerelemei újrahasznosításával kívántak biztosítani. A próbatöltények előállításához térítés ellenében 150 kilogramm (megfelelő minőségű) lőport igényeltek. Mivel kincstári megrendeléshez kapcsolódott a megrendelés, a legalacsonyabb vételár megállapítását kérték.
A nehéz géppuskák fejlesztésén dolgozó üzem töltényés lőporigénylését térítés ellenében történő teljesítését elrendelő minisztériumi döntés érthetetlen, mivel a katonai rendeltetésű fejlesztések költségei hosszú évekig a céget terhelték. Például az 1940. év (állandó) költségei között a két házi konstruktőr kísérleti kiadásai önálló tételként szerepeltek. ${ }^{48}$

6. táblázat. Kísérleti költség 1940 (pengő)

\begin{tabular}{|l|c|r|}
\hline Megnevezés & Gebauer Ferenc & Király Pál \\
\hline Bér & 3130048 & 1547418 \\
\hline Anyag & 302750 & 81907 \\
\hline Egyéb & 296504 & 724789 \\
\hline \multirow{2}{*}{ Összesen } & 3729302 & 2354113 \\
\cline { 2 - 3 } & \multicolumn{2}{|c|}{6083415} \\
\hline
\end{tabular}

1942. augusztus 28-án a berlini katonai attasé továbbította a német katonai vezetés kérdéseit a magyar 12,7 milliméteres harckocsi géppuskáról.

- A Danuvia Fegyver- és Lőszergyár Részvénytársaság által a magyar páncélos csapatok részére szerkesztett D-41 jelzetű lőfegyvert rendszeresítették-e?

- Amennyiben rendszeresítették, akkor a páncél- és harckocsikba beépítették-e, vagy mint páncélelhárító lőfegyvert más módon felhasználták-e?

A Honvédelmi Minisztérium választervezete szerint tervezték a beépítését, azonban a 8 milliméteres géppuska mellett beépített nagyobb űrméretű páncéltörő lőfegyver (pl.: 1941M 40 milliméteres harkocsiágyú) mellett nem látszott szükségesnek beépítése. Ha később szükségesnek ítélték volna a nehézgéppuska beépítését, akkor azt a német 15 milliméteres nehézgéppuskával (2000 darab 15, vagy 20 milliméteres nehézgéppuska és 8000 darab nehéz géppuskacső gyártási jogát a Honvédelmi Minisztérium 1942. július 23-án megvásárolta) kívánták megoldani, mert nem látták gazdaságosnak a repülőgép nehéz géppuskához hasonló lőfegyver gyártására berendezkedni. ${ }^{49}$

1943. április 2-án a Haditechnikai Intézet jelentette, hogy a svájci Hispano-Suiza nehéz géppuska 1936M 20 milliméteres töltényre átépített mintája elkészült. A beérkező lőfegyver kipróbálást 5-6 hét alatt tervezték elvégezni, azonban a próba, alkatrésztörés miatt félbeszakadt. A cseredarabot pótolták, azonban a gyártó cég szerelőjének megérkezéséig a próba továbbra sem volt folytatható. 1943. május 27-én a körülmények elbizonytalanodása miatt törölték a további lőpróbát.50

\begin{tabular}{|c|c|}
\hline Király-féle (K. K. m. 40) & Gebauer-féle \\
\hline Harckocsi & Harckocsi \\
\hline &
\end{tabular}

17. ábra. 20 milliméteres kísérleti nehéz géppuska ${ }^{51}$ 
A. A KIRÁLY-FÉLE K. K. M. 40-ES 20 MILLIMÉTERES NEHÉZ GÉPPUSKA

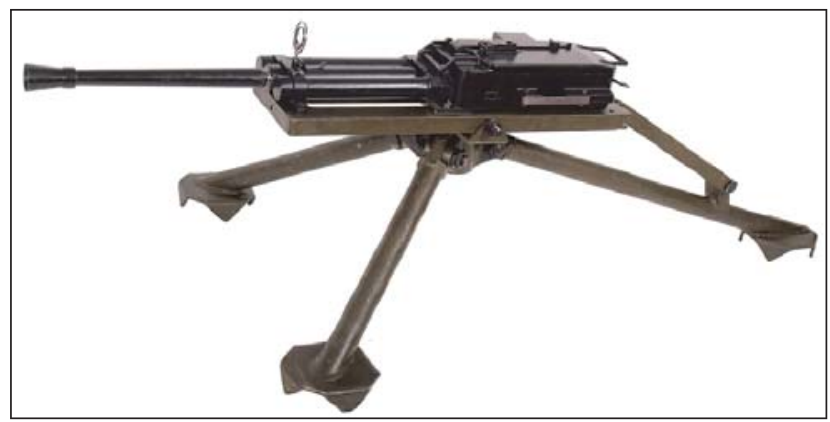

18. ábra. Király-féle kísérleti nehéz géppuska fegyverállványon ${ }^{52}$

- A jelzet magyarázata

7. táblázat. Király-féle nehéz géppuska jelzete

\begin{tabular}{|l|l|}
\hline Jelzet & Magyarázat \\
\hline K. K. m. 40 & $\begin{array}{l}\text { A fejlesztő üzem (Danuvia Fegyver és } \\
\text { Lőszergyár Részvénytársaság) } \\
\text { tervdokumentáció jelzete }\end{array}$ \\
\hline K. K. & $\begin{array}{l}\text { Konstruktőr } \\
- \text { Király Pál főmérnök } \\
\text { - Kucher József (mérnök, később } \\
\text { főmérnök) })^{55}\end{array}$ \\
\hline m. 40 & $\begin{array}{l}\text { A fejlesztés befejezésének, } \\
\text { rendszeresítésének tervezett időpontja } \\
(1940 \text { M) }\end{array}$ \\
\hline
\end{tabular}

Rendeltetése: harckocsi (pl.: 1938M Toldi könnyű harckocsi) nehéz géppuska.

Leírása: A nehéz géppuska kivitele a hagyományos (forgácsoláson alapuló), technológia jellemzőit tükrözi. A szerkezeti elemeinek megmunkálása (pl.: élek, illesztések stb.) és azok felületvédelme (pl.: barnítás) nem utal kísérleti mintára. Karakterisztikája és részegységei (pl.: az adogató, a zár és a reteszelés, elsütőszerkezet stb.) egyediséget tükröz. Összehasonlítva a korabeli nehéz géppuskákkal és azok részegységeivel megállapítható, hogy a konstruktőrnek nem volt miért szégyenkeznie produktuma miatt.

Müszaki jellemzése:

- mozgócsövű, hosszú csőhátrasiklású,

- szilárd reteszelésü,

- tömbzáras (vízszintesen mozgó),

- vegyes tüzelésű,

- egyutas töltésű: az előremozgó tölténytoló töltényhevederből a soron következő töltényt közvetlenül, egyenes vonalon a töltényűrbe továbbította,

- irányzék: 1936M 20 mm-es nehéz puska irányzék és MG 15-ös géppuska körcélgömb.

- fegyverállvány: esetlen, nehéz, valószínűsíthetően csak a lőfegyver gyári, műszaki próbák biztonságos végrehajtását szolgálta.

- Technikai (mérhető) adatai

○ Ürméret (mm):

- Súlya (kg):

o Hossza: (mm):

o Tok:

- hosszúsága (mm):

- szélessége $(\mathrm{mm})$ :

- magassága $(\mathrm{mm})$
○ Cső:

- hosszúsága (mm): $\quad 788$

- lángrejtő hossza (mm): 100

- Irányzóvonal hosszúsága (mm): 475

- Cső hátrasiklása:

- újratöltéskor (mm):

- kireteszelés befejezéséig $(\mathrm{mm})$ :

- kireteszelés megkezdéséig ( $\mathrm{mm}$ )

- elsütést követően /ütőszeg rejtése/(mm):

- Fegyverállvány (ideiglenes):

- formája:

- magassága (mm):

- mellső lábak kiterpesztése (mm):

- hátsó láb hátranyúlása $(\mathrm{mm})$ :

- fegyverfelfogó platform: $>$ szélessége $(\mathrm{mm})$ :

$>$ hosszúsága $(\mathrm{mm})$ :

○ Töltény:

\section{- Fegyverismeret}

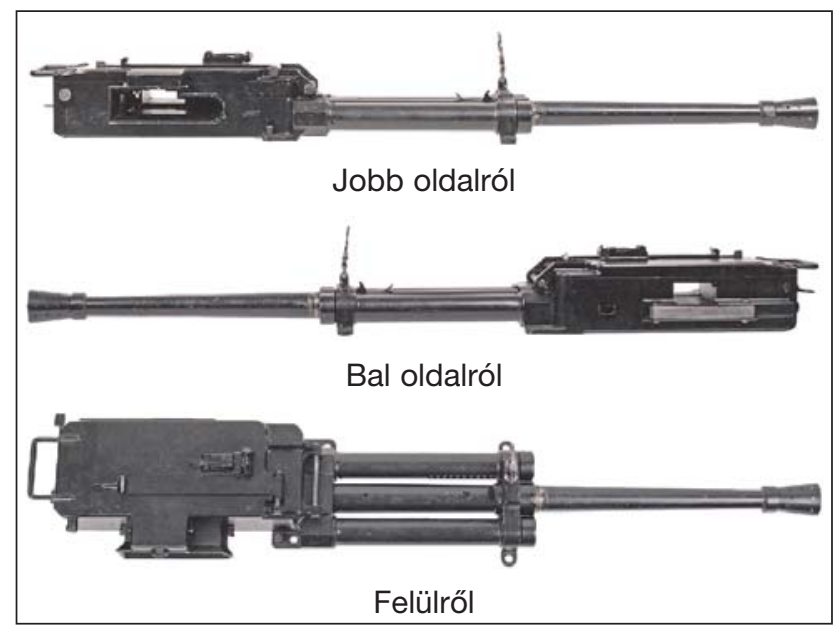

19. ábra. A nehéz géppuska nézeti felvételei ${ }^{56}$

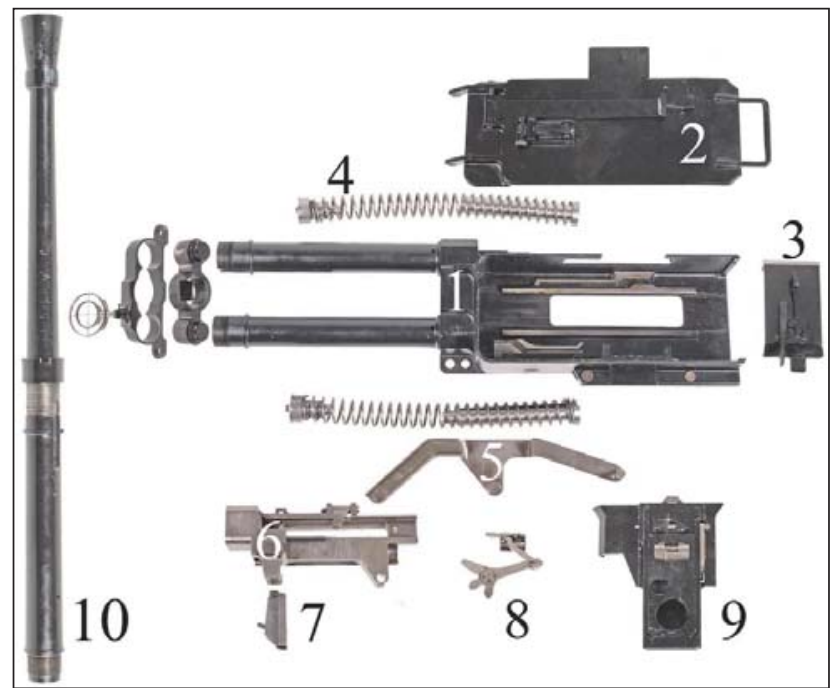

20. ábra. A nehéz géppuska szerkezeti elemei ${ }^{57}$

1. tok a csőrugó-vezetővel, 2. tokfedél a zármozgatóval,
3. tokfar az elsütőszerkezettel, 4. csőrugó, 5. himba,

6. csőtoldalék, 7. zár, 8. tölténytoló/hüvelyvonó,

9. hevedertok 
- Fő részek és rendeltetésük ${ }^{58}$

- Cső: biztosította a lövedék forgó mozgását, kezdősebességét és induló irányát.

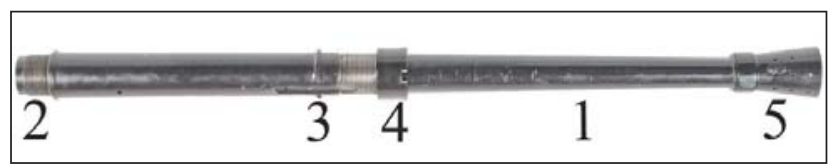

21. ábra. A cső

1. cső, 2. csőtoldalék-foglalvány, 3. csőrögzítő perem,

4. csőanya, 5. lángrejtő

- Csőtoldalék: egy egységbe kapcsolta és működtette a szerkezeti elemeket.

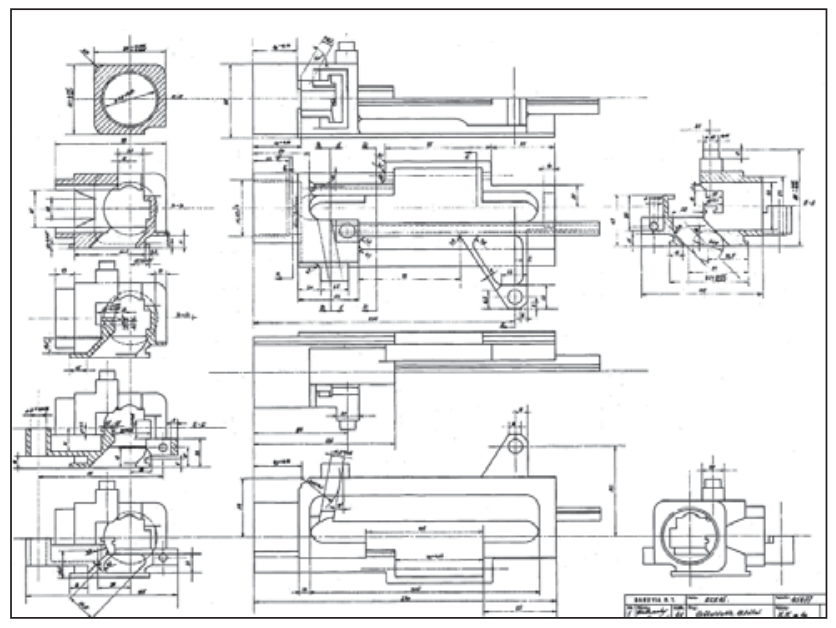

22. ábra. Tervdokumentációo 59

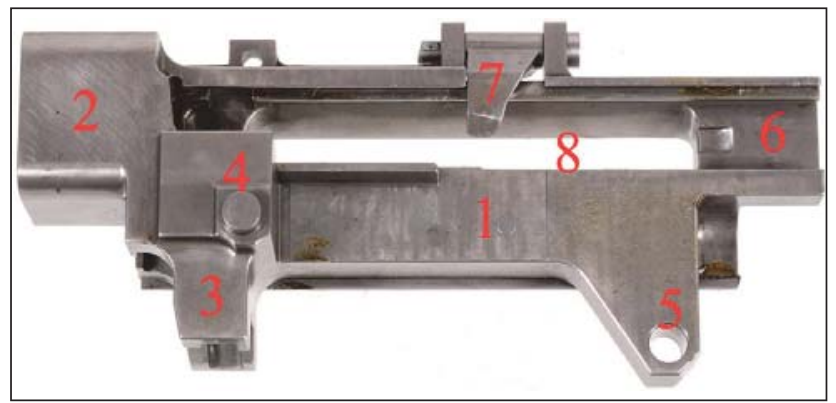

23. ábra. Nehézgéppuska szerkezeti eleme

1. csőtoldalék, 2. csőfoglalvány, 3. zárvezető, 4. himbave-

zérlő szemölcs, 5. tölténytoló/hüvelyvonó mozgató áttöret,

5. tölténytoló/hüvelyvonó vezetőpálya, 6. kivető,

7. kivetőnyílás

- Tok: összetartja a fegyver fő részeit, befogadja és vezeti a mozgó alkatrészeket, valamint helyet ad az elsütőszerkezetnek és a hevedertoknak.

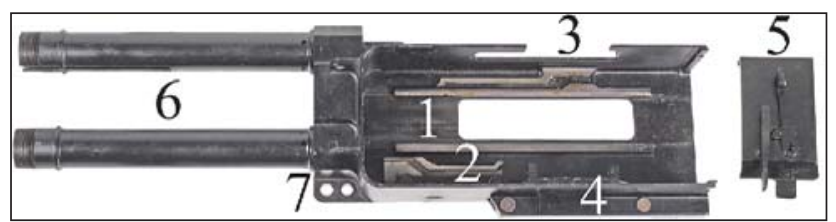

24. ábra. Nehézgéppuska szerkezeti eleme

1. tok, 2. zár és csőtoldalék vezetőpálya, 3. hevedertok-fészek, 4. tölténytoló/hüvelyvonó mozgásvezérlö, 5. tokfar az elsütőszerkezettel, 6. helyretolórugó/ütköző ház, 7. hátsó rögzítőelem

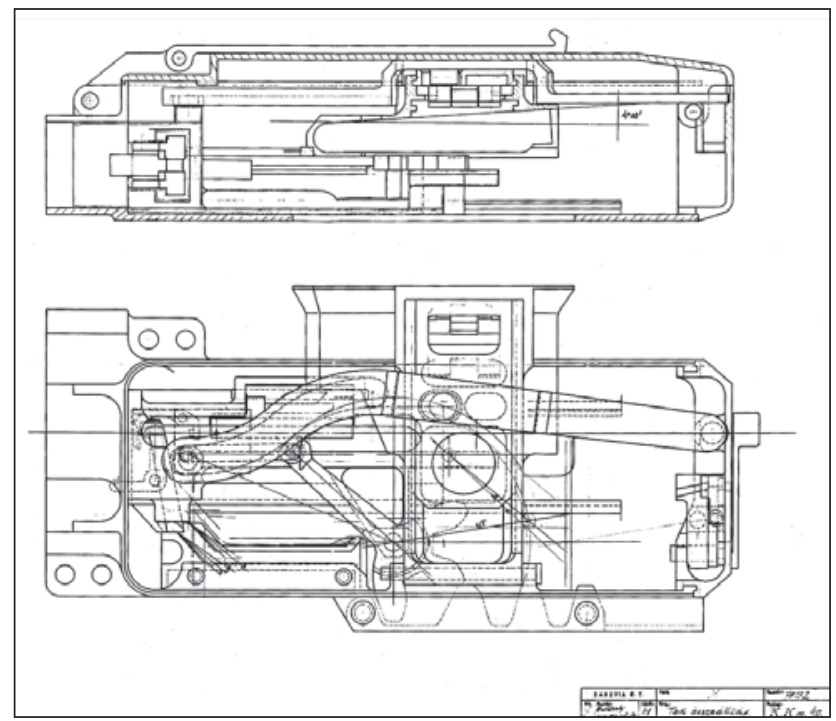

25. ábra. A tok tervdokumentációja ${ }^{60}$

- Tokfar-fedél: a tok végének biztonságos lezárásán túl, helyet ad az elsütőszerkezetnek, valamint

\begin{tabular}{|l|l|}
\hline $\begin{array}{c}\text { Üzemmód kapcsolók/ } \\
\text { elsütő karok }\end{array}$ & \multicolumn{1}{|c|}{ Elsütőszerkezet } \\
\hline $\begin{array}{l}\text { 1. tokfar-fedél, 2. } \\
\text { egyeslövés-, } \\
\text { 3. sorozatlövés kapcsoló } \\
\text { (elsütő karok) }\end{array}$ & $\begin{array}{l}\text { 1. tokfar-fedél, 2. biztosító, } \\
\text { 4. elsütöemelö, } \\
\text { 5. sorozatövés-, } \\
\text { 6. himba hátsó foglalványa }\end{array}$ \\
\hline
\end{tabular}

\section{6. ábra. Tokfar-fedél}

Az elsütőszerkezet működése:

$>$ A biztosító megakadályozta, hogy nyitott tokfedélnél ki lehessen váltani a lövést, illetve mellső helyzetbe „futtatni" a mozgó alkatrészeket.

$>$ Egyeslövésnél: a jobb oldali elsütőkar lenyomását követően megszúnt a kényszerkapcsolat a szerkezeti elemek és az elsütőemelő között, így az felemelkedve megakasztotta a hátravetődő mozgóalkatrészeket.

> Sorozatlövésnél: a bal oldali elsütőkar működtetése folyamatosan alsó helyzetben tartotta az elsütőemelőt, így az elsütőnyugasz akadálytalanul átsiklott felette. A tüzelés részmúveleteinek ciklikus ismétlődését az elsütőkar felengedésével lehetett beszüntetni.

- Tokfedél: a tok biztonságos lezárásán túl, helyet adott az irányzéknak és a felhúzó karnak.

27. ábra. A tokfedél

1. tokfedél, 2. hevedertok fedél, 3. mellső rögzítő fül,

4. kezelőfogantyú, 5. 1936M $20 \mathrm{~mm}$-es nehéz puska irányzék,

6. felhúzókar

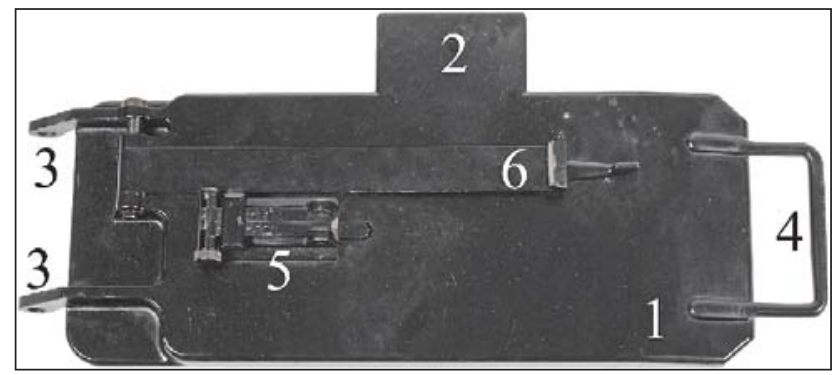




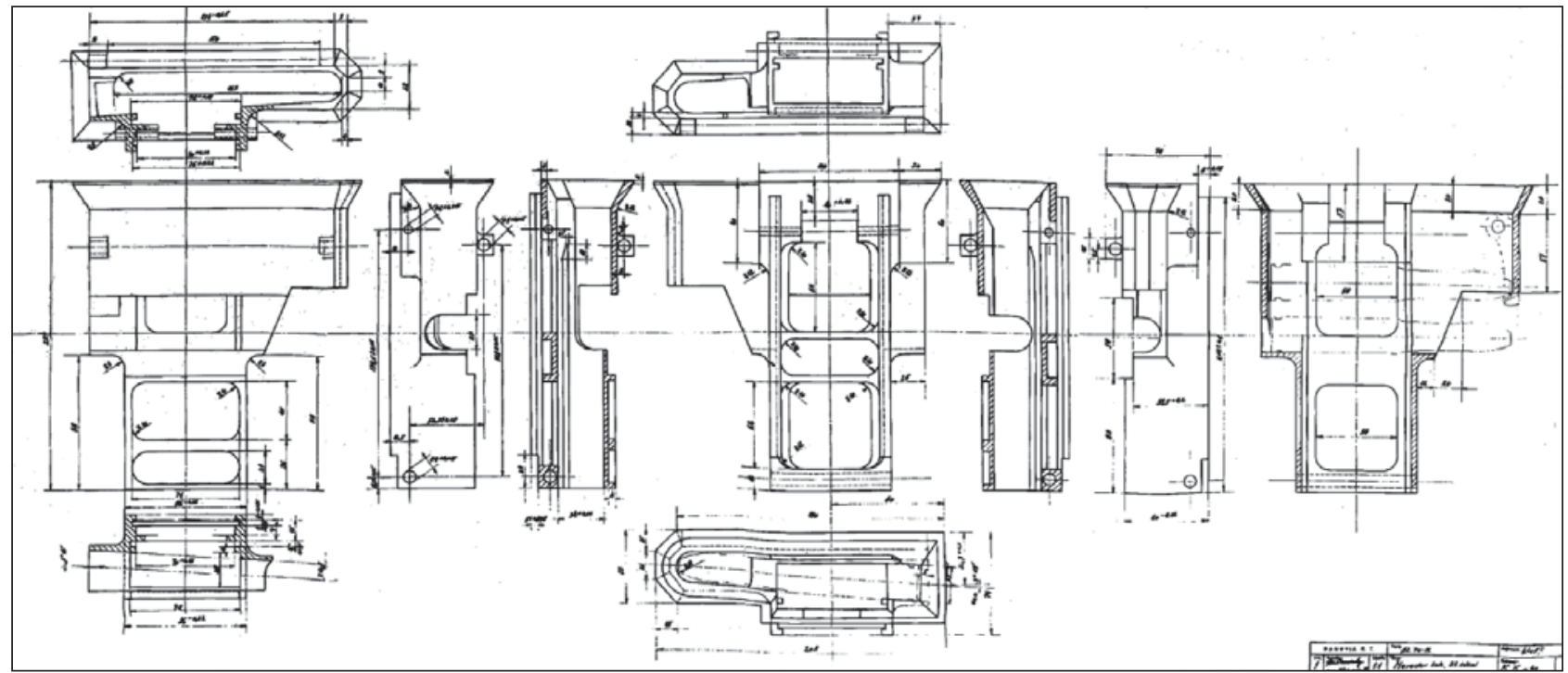

28. ábra. Hevedertok tervdokumentáció61

- Hevedertok: töltött töltényheveder mozgatása, a soron következő töltény eljuttatása és megállítása a töltényvonó tengelyvonalában.

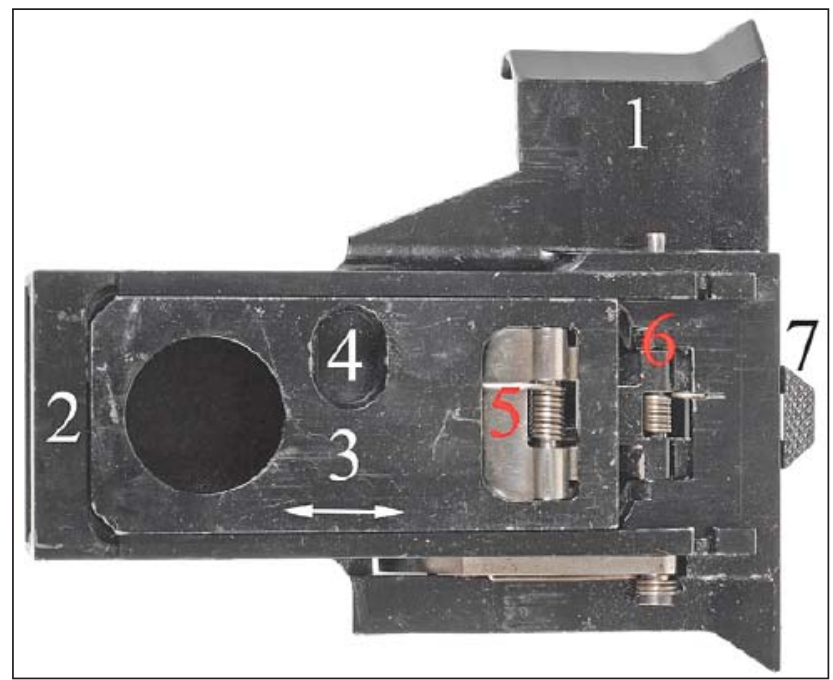

29. ábra. Nehézgéppuska szerkezeti elem

1. töltényterelö, 2. hevedercsatorna, 3. adogatócsúszka,

4. himbacsap foglalvány, 5 . adogatókilincs,

6. hevederakasztó, 7. hevederakasztó működtető nyúlvány

- Csőrugó: lövést követően rugalmas ütközéssel a hátsó holtponton megálította, majd mellső helyzetbe tolta a mozgó alkatrészeket.

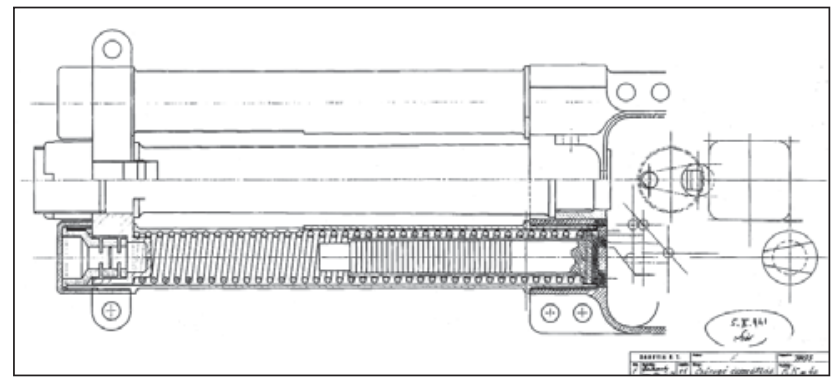

30. ábra. Csőrugó tervdokumentáció ${ }^{62}$

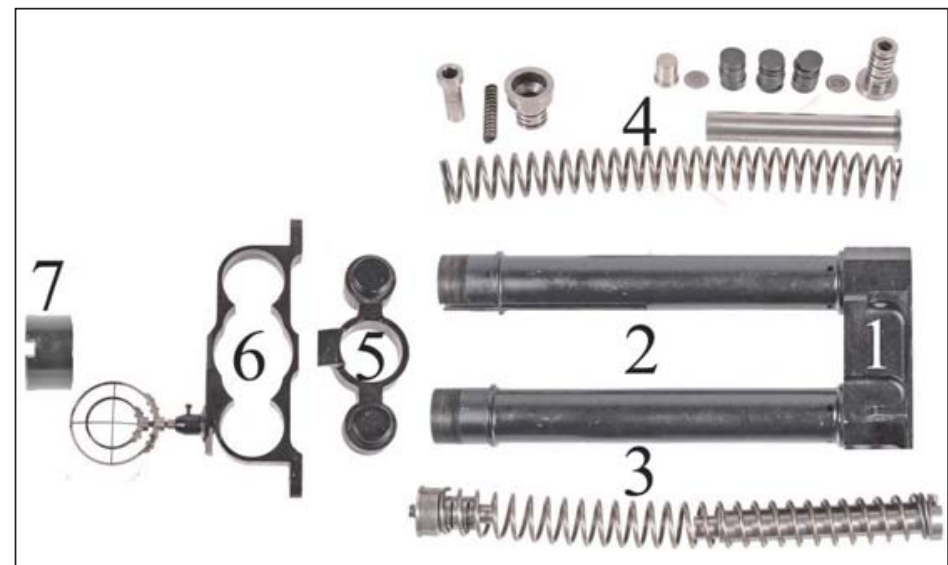

31. ábra. Nehézgéppuska szerkezeti elemei

1. tok, 2. rugóvezetö, 3. szerelt csőrugó, 4. csőrugó elemei, 5.

csőrugótámasz, 6. mellső rögzítő elem/körcélgömb tartó, 7. csőanya (a beillesztett csőre szerelhetô)

- Zár: lövés időszakában lezárta a csőfart (a töltést és ürítést önálló szerkezeti elem végezte).

32. ábra. Szerkezeti elem

1. zártest, 2. vezetőlécek, 3. határoló, 4. peremágy,

5. ütőszeg

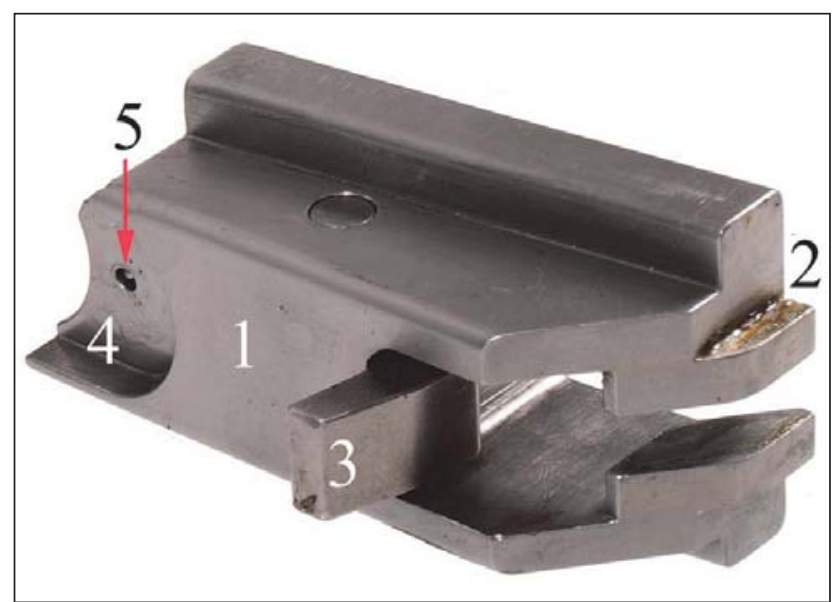

$64 \Rightarrow$ HADITECHNIKA LI. évf. 2017/4 


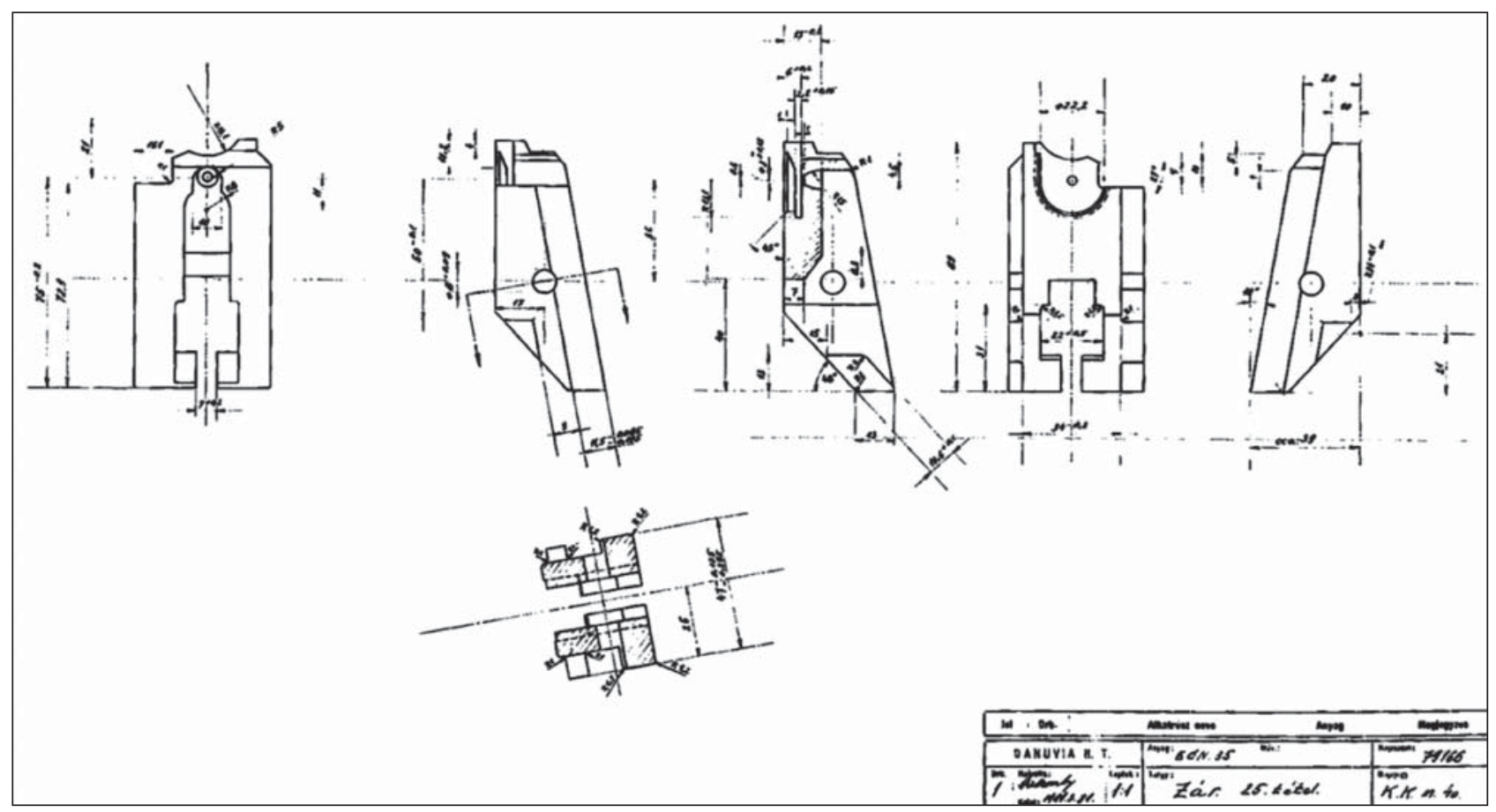

33. ábra. Tervdokumentációo ${ }^{3}$

- Himba: összekapcsolja a csőtoldalékot az adogatócsúszkával és vezérli annak mozgását.

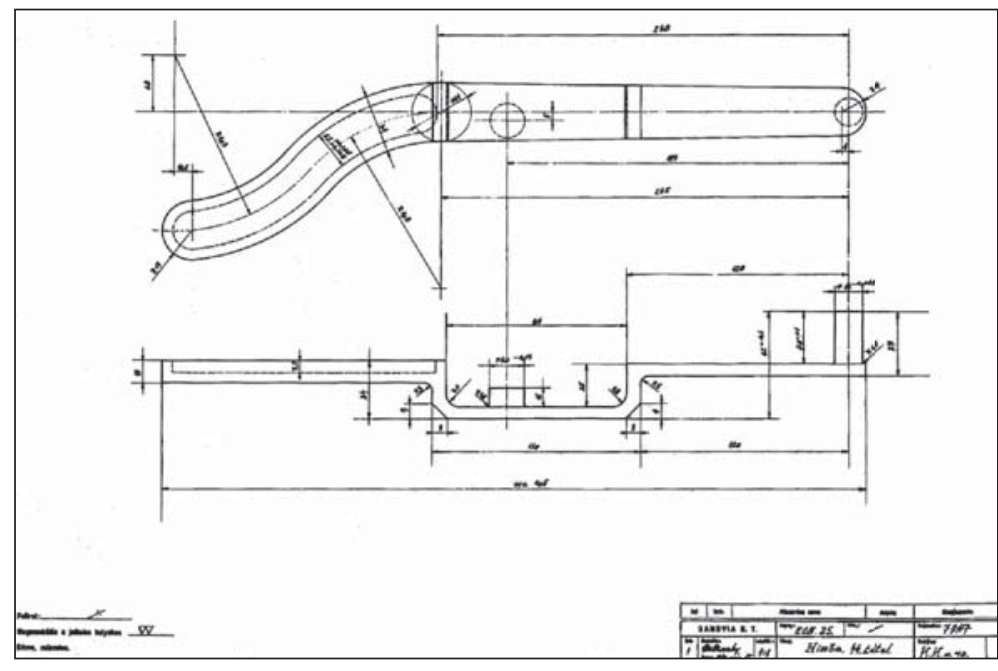

34. ábra. Tervdokumentáció ${ }^{4}$

- Tölténytoló/hüvelyvonó: tölt és ürít, valamint mellső mozgatókarja tűzkésszé tételkor, öntöltő üzemmódban (egyeslövéskor) és (ideiglenes, vagy végleges) tüzbeszüntetéskor a hátsó holtponton megakasztotta a mozgó alkatrészeket.

36. ábra. Tölténytoló/hüvelyvonó 1. tölténytoló beszabályozó, 2. hüvelyvonó, 3. mozgatókarok 4. léptető fogak, 5. elsütőnyugasz (alsófelületen), 6. csőtoldalék kapcsolócsap (alsófelületen)

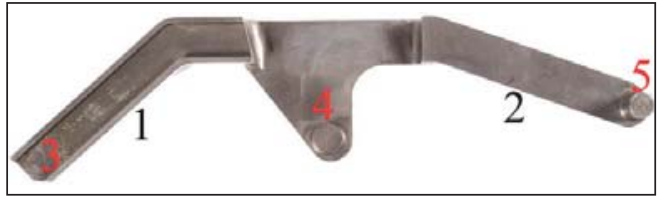

35. ábra. Szerkezeti elem (módosított)

1. mellsőkar, 2. hátsókar, 3. csőtoldalék csap kényszerpálya, 4. adogatócsúszka mozgatócsap, 5. tokfar csap

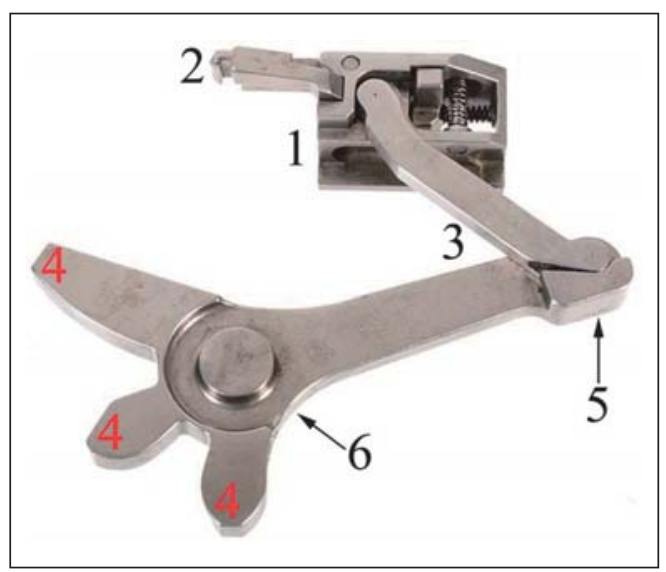




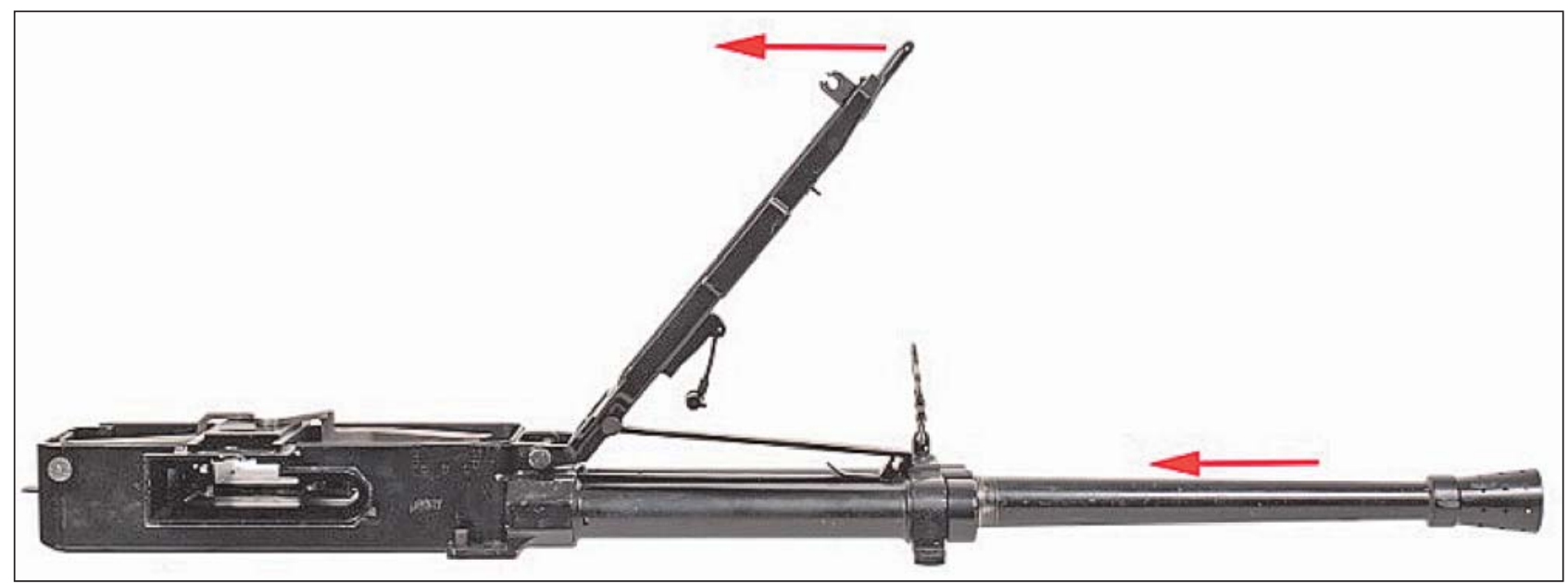

37. ábra. A tǔzkésszé tétel

- A nehéz géppuska müködése ${ }^{65}$

- Túzkésszé tétel

- a hevedert befüzték a hevedertokba,

- a csőrugók összenyomásával a csövet a csőtoldalékkal hátra feszítették,

- a mozgó alkatrészek hátrasiklása közben egyrészt a zár balra kimozdult a csőfar mögül (kireteszelés), másrészt a tölténytoló/hüvelyvonó megindult hátra, harmadrészt az első töltény a töltőpályába kényszerült,

- végül a tölténytoló/hüvelyvonó mozgatókarja hátsó helyzetbe fordult és elsütőnyugasza az elsütőemelőbe kapcsolódott,

- a nehéz géppuska tűzkésszé vált..66

- Lőfegyverhasználat

- a lőfegyver tüzelési üzemmódjának megfelelő kar (üzemmód-kapcsoló) megválasztása,

- elsütőkar lenyomását követően, a cső és a csőtoldalék, a csőrugók hatására előre siklottak,

- a csőtoldalék a kapcsolt szerkezeti elemeket, a tölténytoló/hüvelyvonót, a himbát és a zárat is mozgásra kényszerítette, egyrészt a töltény a töltényürbe került (töltés), másrészt a zár lezárta a csőfart (reteszelés), végül az ütőszeg közbeiktatásával kiváltotta a lövést (elsütés),

- lőportöltet égésekor keletkező gáznyomás a lövedéket előre, a hátralökő erő a mozgó alkatrészeket hátra kényszerítette,

- $\mathrm{a} \sim$ 1:2 áttétezés következtében a tölténytoló/hüvelyvonó elvált a csőfartól az üres hüvelyt kivonta a töltényűrből (ürítés), majd a kivető nyíláson keresztül eltávolította a tokból (kivetés),

- amikor a mozgó alkatrészek a hátsó holtpontra jutottak:

$>$ sorozatlövéskor a tölténytoló/hüvelyvonó mozgatókar elsütőnyugasza az alsó helyzetben tartott elsütőemelő felett akadálytalanul átsiklott, így a tüzelés részműveletei (a töltés, a reteszelés, az elsütés és az ürítés) folyamatosan követték egymást, ameddig a töltény el nem fogyott, illetve az irányzó az elsütőkart fel nem engedte,

$>$ egyeslövéskor az elsütőnyugasz és az elsütőemelő összekapcsolódott, a lövést az elsütőkar felengedését követően lehetet ismételni.

$66 \rightarrow$ HADITECHNIKA LI. évf. 2017/4

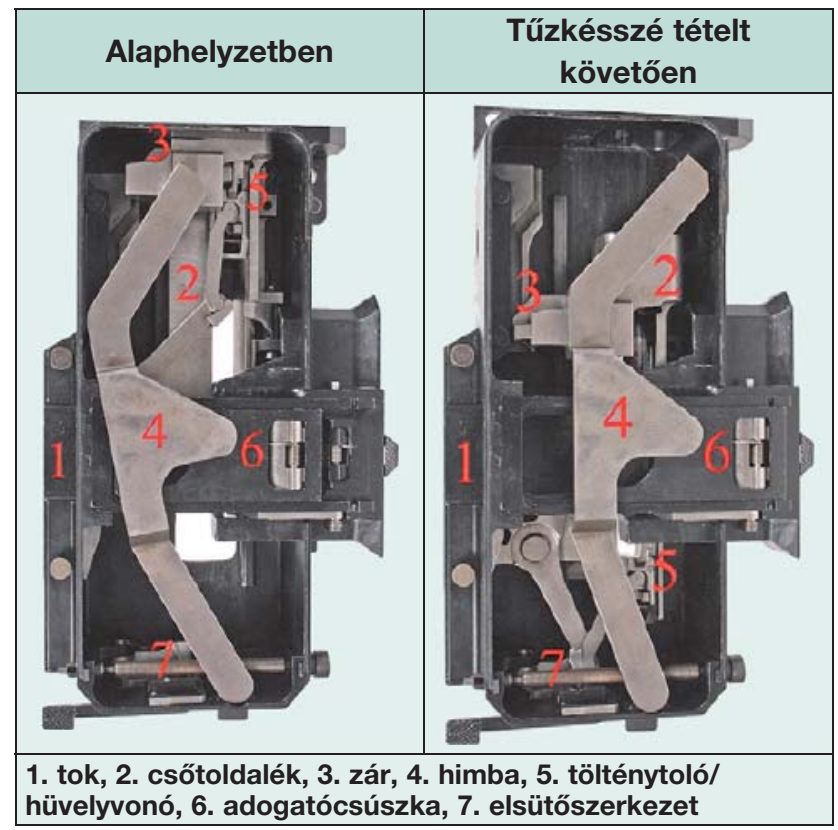

38. ábra. Mozgó alkatrészek helyzete I.

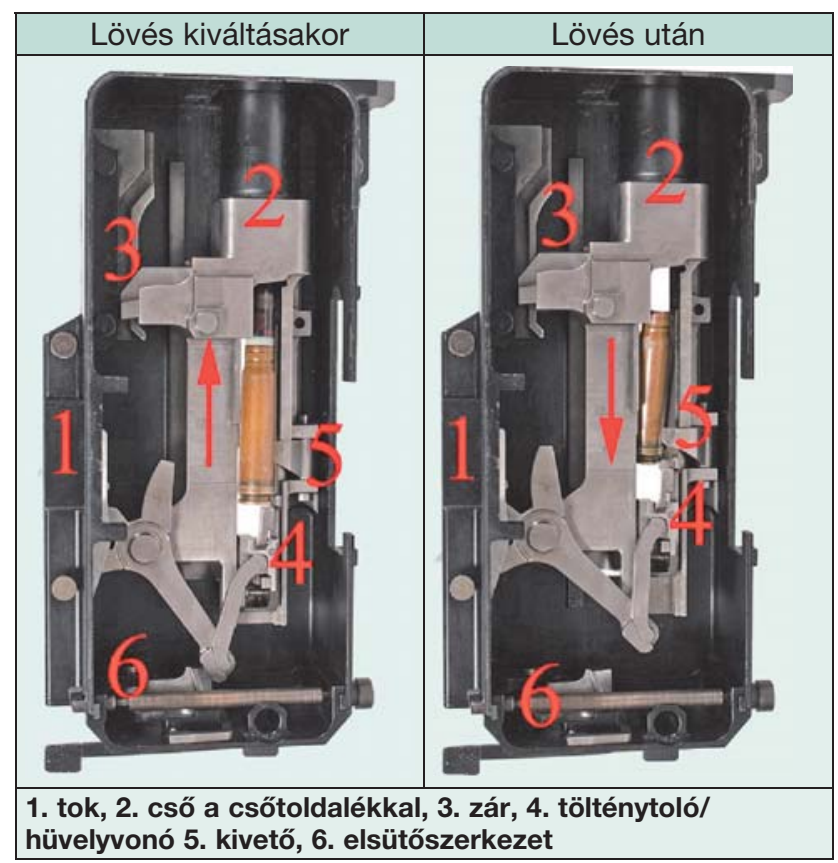

39. ábra. Mozgó alkatrészek helyzete II. 


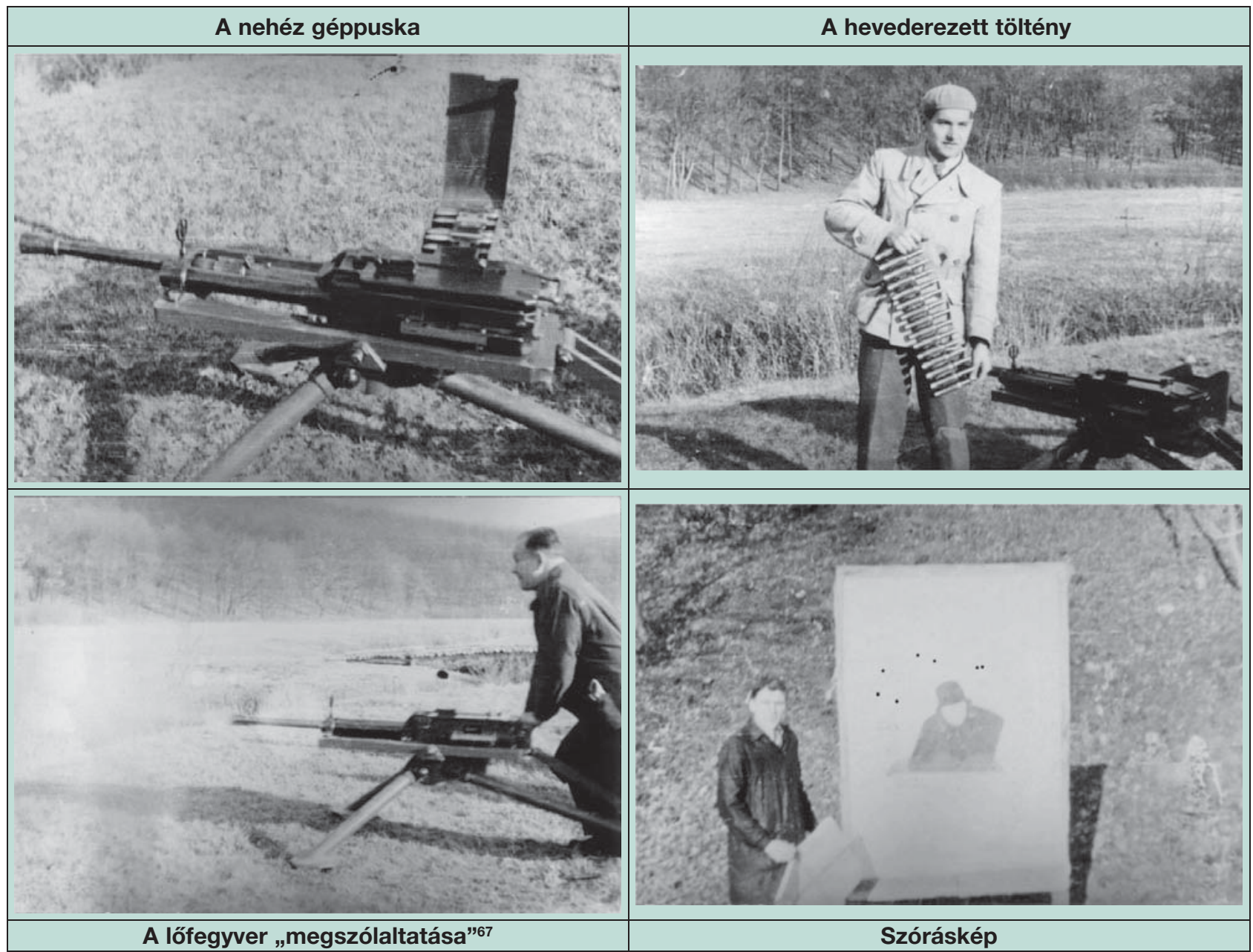

40. ábra. A Király-féle nehéz géppuska üzemi próbája

\section{B. A GEBAUER-FÉLE NEHÉZ GÉPPUSKA}

Gebauer Ferenc nem fegyvercsalád-elv napjainkban megfogalmazott előnyeire alapozva (pl.: előállítás, kiképzés stb.) szerkesztette lőfegyvereit, de a különböző rendeltetésű (pl.: 1934M megfigyelő-, 1934/37AM harckocsi- stb.) géppuskáin azonos szabadalmi modulok (pl.: három részből álló závárzat - zárszerkezet) találhatók. ${ }^{69}$

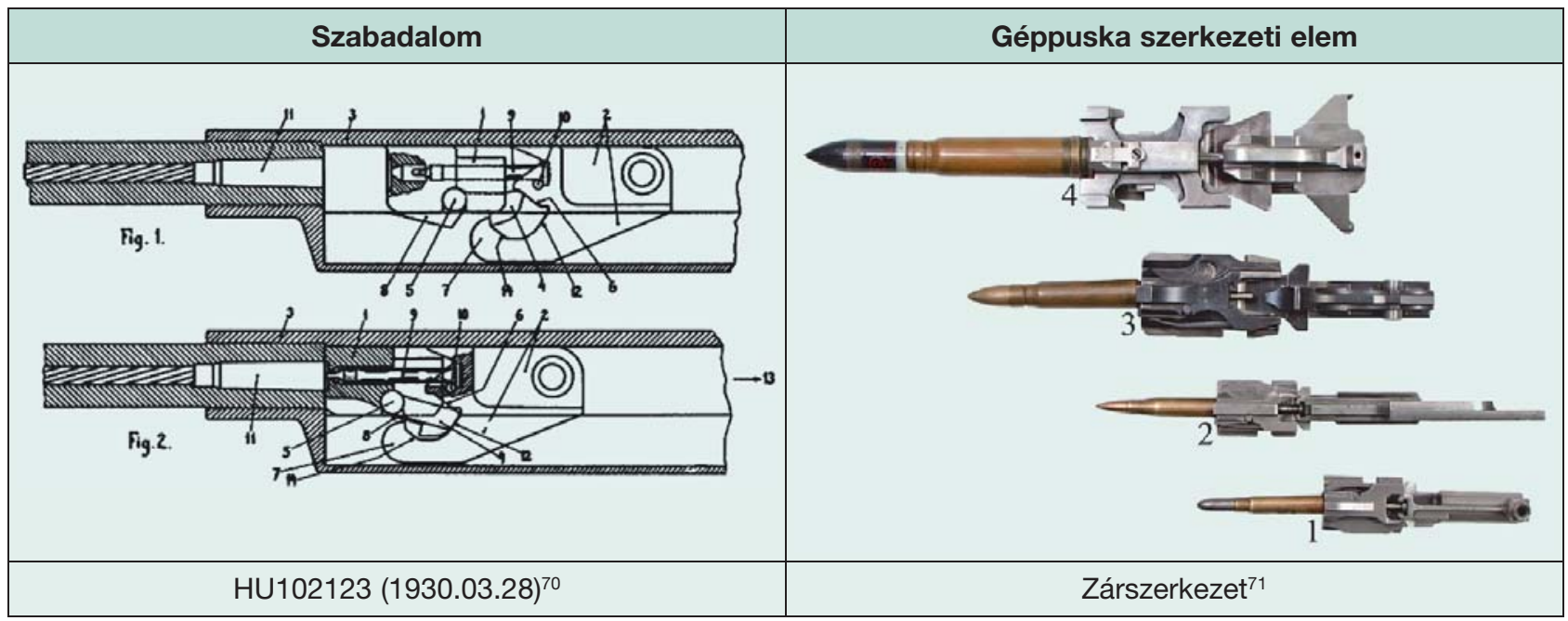

41. ábra. Gebauer-féle lőfegyver závárzat 


\section{JEGYZETEK}

39 Hadtörténelmi Levéltár: HM 1941elnöki 3a osztály 6459; Pro domo;

40 A Haditechnikai Intézet a Madsen nehéz a géppuskát és töltényeit 47000 pengőért kapta meg kipróbálásra;

41 Hadtörténelmi Levéltár: HM 1932 elnöki 3a osztály 103680;

42 Hadtörténelmi Levéltár: Haditechnikai gyüjtemény 228/3;

43 Hadtörténelmi Levéltár: 1937/3a osztály szám nélkül;

44 Hadtörténelmi Levéltár: HM 1943 elnöki 3a osztály 84483 (54055: Harckocsi és páncélgépkocsi fegyverzetre hiteligénylés 2-9 o.);

45 Hadtörténelmi Levéltár: HM 1943 elnöki 3a osztály 84483 (54055: Harckocsi és páncélgépkocsi fegyverzetre hiteligénylés 16-20 o.);

46 Hadtörténelmi Levéltár: HM 1943 elnöki 3a osztály 84483 (54055: Harckocsi és páncélgépkocsi fegyverzetre hiteligénylés 21-22 o.);

47 Hadtörténelmi Levéltár: HM 1940 elnöki 3c osztály 18440;

48 1. Hadtörténelmi Levéltár: 2399 csomó/HM 1941elnöki 3c osztály 75841; 2. Hadtörténelmi Levéltár: HM 1941elnöki 3a osztály 4464 csomó 551089; 3. Budapest Főváros Levéltára XI.187/f. Danuvia Fegyver és Lőszergyár RT. Pénzügyi iratok 1935-1941; 1. doboz; 1940. év különféle költségei \%-ban;

49 1. Hadtörténelmi Levéltár: HM 1942 elnöki 3a osztály 52481 (Kérdések-fordítás); 2. Hadtörténelmi Levéltár: HM 1942 elnöki $17 r$ osztály 105003 (Licencvásárlás); 3. A 151 M és 151/20 M repülőgép géppuska ismertetése, működése, kezelése és karbantartása Honvédelmi Minisztérium Budapest 1943;

50 Hadtörténelmi Levéltár: HM 1943 elnöki 3a osztály 15741;

51 Szikits Péter felvétele;

52 Szikits Péter felvétele,

53 A lőfegyverjelzet azonosításának alapja: a konstruktőr Király Pál (Lőtsös-féle hűtlenségi per II. rendű vádlottja) lakásán lefoglalt műszaki rajzok és egyéb dokumentumok; > ÁBTL: V-122702/e jelzetű dosszié 153-171 tervrajz;

54 A csőrugó összeállitásának tervrajzát Király 1941. február 5-én (talán jóváhagyásként) szignálta; Állambiztonsági Szolgálatok Történelmi Levéltára: ÁBTL-3.1.9.-121702/e/129 számú műszaki rajz;

55 Király Pál és Kucher József együttműködése nem volt új keletű, az $1939 \mathrm{M} 9$ mm-es géppisztoly tervezése és gyártása idejére datálható; 1. Eötvös Péter - Hatala András - Soós Péter: A király géppisztoly Hadtörténeti Intézet és Múzeum/Zrínyi Kiadó Budapest, 201442 o.; 2. Pap Péter: Kucher József mérnök ezredes. A Hadtörténeti Múzeum értesítője 14 Hadtörténeti Múzeum, 2014. 91-94 o. (Király Pál, Kucher József és a Danuvia Ipari és Kereskedelmi Részvénytársaság közösen jegyezték be az 1939M 9 mm-es géppisztoly szabadalmát.; 3. Hadtörténelmi Levéltár (továbbiakban HL): HM. 1941 Elnöki 3/a osztály 3537; (1938. január 1. - június 30. közötti időszakban a Danuvia Ipari és Kereskedelmi Részvénytársaság fizetés-részletezésében Kucher József a „Király kísérlet” rovatban szerepelt, 4. o.) 4. A nehéz géppuska üzemi próbáján készült fényképek Kucher József hagyatékából származnak;

56 Szikits Péter felvételei;

57 Szikits Péter felvételei;

58 Szikits Péter felvételei;

59 Állambiztonsági Szolgálatok Történelmi Levéltára: ÁBTL-3.1.9.-121702/e/ 131 számú műszaki rajz;

60 Állambiztonsági Szolgálatok Történelmi Levéltára: ÁBTL-3.1.9.-121702/e/130 számú müszaki rajz;

61 Állambiztonsági Szolgálatok Történelmi Levéltára: ÁBTL-3.1.9.-121702/e/149-150 számú műszaki rajz;

62 Állambiztonsági Szolgálatok Történelmi Levéltára: ÁBTL-3.1.9.-121702/e/129 számú műszaki rajz; 63 Állambiztonsági Szolgálatok Történelmi Levéltára: ÁBTL-3.1.9.-121702/e/143 számú műszaki rajz 64 Állambiztonsági Szolgálatok Történelmi Levéltára: ÁBTL-3.1.9.-121702/e/152 számú műszaki rajz;

65 Szikits Péter felvétele;

66 A nehézgéppuska, (mint az automata lövészfegyverek többsége), nem töltött csőre, csak cső elé, mivel huzamosabb lövéskor a csővel együtt a töltényür is felhevült és ideiglenes tűzbeszüntetéskor vétlenlövés is bekövetkezhetett. Például a 7,62 mm-es korszerűsített 1943M (KGK) géppuskánál folyamatosan leadott 250 lövést követően 15-20, 500 lövés után 7-10 másodperc múlva következhet be a töltény öngyulladása; 67 Hagyomány szerint az első sikeres lőpróba megnevezése (talán utalás volt a lövést kísérő torkolatdörejre); 68 1. Ismeretlen lőtéren és időpontban; 2. Kucher József hagyatékából;

69 Pap Péter: Adattár Gebauer Ferenc fegyverkonstruktőr pályafutásához HADTÖRTÉNELMI KÖZLEMÉNYEK 2012/3 687-690 o.;

70 Szellemi Tulajdon Nemzeti Hivatala Elektronikus kutatás (továbbiakban: SZTNH); Azonosító: HU102123;

71 1. 1930 M 8 mm-es, 2. 1931 M 8 mm-es, 3. 1940 M 12,7 mm-es, 4. 1936 M 20 mm-es töltényeket felhasználó automata lőfegyverek zárszerkezetei (legkönnyebb: 0,388, legnehezebb: 1,90 kilogramm).

\section{A HADITECHNIKA} FOLYÓIRAT MEGJELENT A FACEBOOK-ON

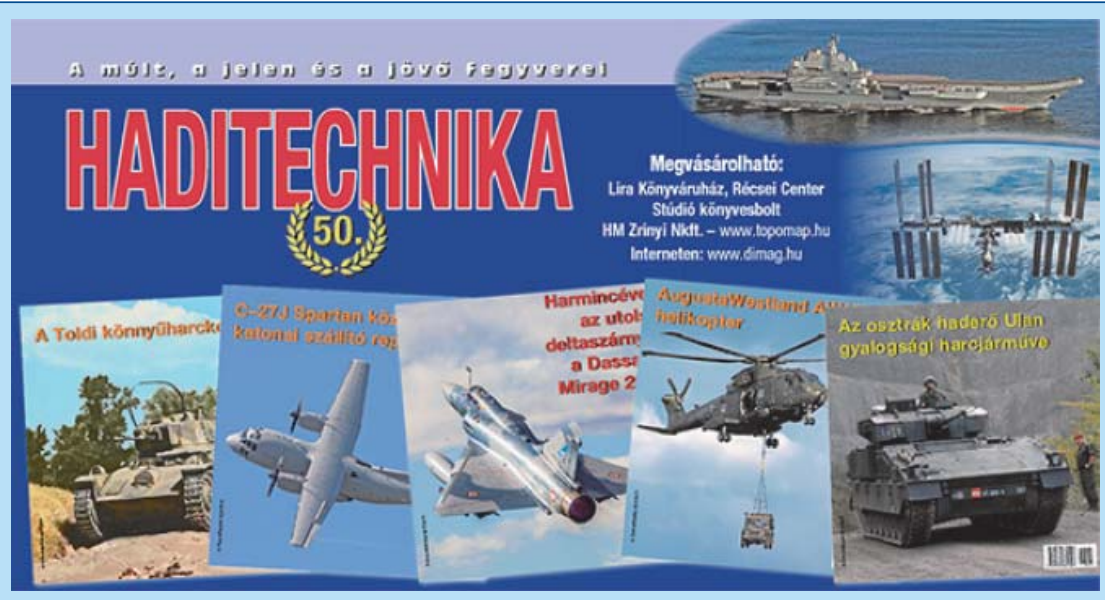

Elérhető: Haditechnika folyóirat@HTfolyoirat, illetve https://www.facebook.com/HTfolyoirat/ 